\title{
ENDOSCOPIC ENDONASAL TRANSSPHENOIDAL SURGERY FOR PITUITARY MACROADENOMA AS MINIMAL INVASIVE APPROACH: CASE REPORT
}

\author{
Febyan $^{1}$, Handrianto Setiajaya ${ }^{2}$ \\ ${ }^{1}$ Faculty of Medicine, Christian University of Krida Wacana, Jakarta. Correspondence: febyanmd @gmail.com. \\ ${ }^{2}$ Neurosurgeon Department, Gatot Soebroto Central Army Hospital, Jakarta.
}

\begin{abstract}
Background: pituitary tumor accounted for $15 \%$ of benign intracranial tumors. Clinical symptoms found in the form of visual disturbances, and hormonal manifestations, surgery is one of the main managements. Endoscopic endonasal transsphenoidal surgery (EETS) is a minimally invasive approach for this case. The advantages of EETS is better efficacy than traditional technique, and shorter hospital stays, less mean blood loss, and earlier return to daily activities. Case: we reported a rare example of a male patient aged 37 years old with the main clinical features were visual disturbances, sexual malfunction and bitemporal hemianopsia on physical examination. Magnetic resonance imaging (MRI) showed macroadenoma pituitary, the size $2.41 \times 2.98 \times 3.20 \mathrm{~cm}$. We explained about minimally invasive surgery such as EETS and the patient was agreed to performed EETS. Conclusion: endoscopic endonasal transsphenoidal surgery is a minimally invasive technique for tumor pituitary cases and safe when compared to traditional medicine.
\end{abstract}

Keywords: endoscopic endonasal transsphenoidal surgery, pituitary macroadenoma, minimal invasive approach.

\section{BEDAH TRANSPENOIDAL ENDOSKOPI ENDONASAL PADA MACROADENOMA HIPOFISIS SEBAGAI PENDEKATAN MINIMAL INVASIVE: LAPORAN KASUS}

\author{
Febyan $^{1}$, Handrianto Setiajaya ${ }^{2}$ \\ ${ }^{1}$ Fakultas Kedokteran, Universitas Kristen Krida Wacana, Jakarta. Korespondensi: febyanmd @gmail.com. \\ ${ }^{2}$ Departemen Bedah Saraf, Rumah Sakit Pusat Angkatan Darat Gatot Soebroto, Jakarta.
}

\begin{abstract}
ABSTRAK
Latar belakang: tumor hipofisis merupakan tumor jinak yang terjadi sekitar $15 \%$ dari beberapa kasus tumor intrakranial. Gejala klinis yang ditemukan berupa gangguan penglihatan dan manifestasi hormonal. Pembedahan merupakan salah satu penatalaksanaan yang utama. Bedah transpenoidal endoskopi endonasal (EETS) merupakan teknik bedah yang invasif minimal untuk kasus ini. Keunggulan EETS memiliki efikasi yang lebih baik dibandingkan teknik tradisional, dan waktu perawatan pasca operasi lebih singkat dan kehilangan darah saat operasi yang minimal sehingga pasien dapat lebih cepat kembali ke aktivitas sehari-hari. Kasus: kami melaporkan sebuah kasus yang jarang ditemukan, seorang pasien laki-laki berusia 37 tahun dengan keluhan klinis berupa gangguan penglihatan, gangguan fungsi seksual dan pada pemeriksaan fisik ditemukan bitemporal hemianopsia. Pemeriksaan magnetic resonance imaging (MRI) didapatkan makroadenoma hipofisis berukuran 2,41 x 2,98 x 3,20 cm. Kami menjelaskan teknik pembedahan yang invasif minimal berupa EETS dan pasien bersedia untuk dilakukan tindakan EETS. Simpulan: Bedah transpenoidal endoskopi
\end{abstract}


endonasal, merupakan tindakan invasif minimal untuk kasus-kasus tumor hipofisis dan lebih aman dibandingkan pendekatan bedah tradisional.

Kata kunci: bedah transpenoidal endoskopi endonasal, makroadenoma hipofisis, tindakan invasif minimal.

\section{INTRODUCTION}

Pituitary tumors accounted for $15 \%$ of benign intracranial tumors. ${ }^{1}$ They often remain undiagnosed, and small pituitary tumors have an estimated prevalence of $16.7 \% .^{2}$ The diagnosis is generally by basis visual impairment arising from the compression of the optic nerve cause the tumor, or based on manifestations of excess hormone secretion. Pituitary adenomas can be differentiated by measuring the size of the tumor. ${ }^{2}$ Pituitary macroadenomas are defined as intrasellar adenomas of less than $1 \mathrm{~cm}$ in diameter without sellar enlargement whereas pituitary macroadenomas measure larger than $1 \mathrm{~cm}$ in diameter with generalized sellar enlargement with symptoms caused the effect of the tumor size. However, giant pituitary adenoma is a rare tumor, and it defined as tumors $4 \mathrm{~cm}$ or greater, it accounts for $5 \%-14 \% .^{2}$

The most common surgical approaches used for the treatment of pituitary macroadenomas are the microscopic transsphenoidal or various frontal and frontotemporal transcranial routes. ${ }^{3}$ Currently, endoscopic endonasal transsphenoidal surgery (EETS) as a minimally invasive technique is the best choice when pituitary surgery indicated with fewer complications. In this case, we reported a rare occurrence with pituitary macroadenoma, and we performed endoscopic endonasal transsphenoidal surgery as the minimally invasive approach to this patient.

\section{CASE REPORT}

A 37-year-old man went to the Gatot Soebroto Central Army Hospital, to undergo surgical treatment of a pituitary tumor. Chief complain there was a visual loss in both eyes and diplopia. Two years before being admitted to the hospital, the patient had noticed sexual malfunction. Hormone testing has shown that the tumor is hormonally inactive. The neurological examination has revealed the chiasmal syndrome failure of the first and second branches of cranial nerve $\mathrm{V}$ on the left side. Ophthalmic examination showed VIS $\mathrm{OD}=\mathrm{OS}=1.0$ and bitemporal hemianopsia. No oculomotor disturbances were detected. Funduscopy showed that the optic disc was discolored with a clear margin and plethoric tortuous veins. The preoperative Karnofsky score was 80. MRI scanning showed a large pituitary tumor. The tumor compresses the chiasm. Tumor size is $2.41 \times 2.98 \times 3.20 \mathrm{~cm}$ (Figure 1). Endoscopic endonasal resection of the macroadenoma pituitary tumor was performed on December 16 $6^{\text {th }}, 2016$.

The typical endoscopic approach to the projection from the anterior wall of the main sinus from the right nasal. The sphenoid sinus and the floor of the sella turcica were opened with Kerrison Rongeur. A moderately bleeding tumor of gray color and moderate density was exposed after the dura mater of the sella turcica were opened. The tumor was removed using currents and a suction device (Figure 2). 


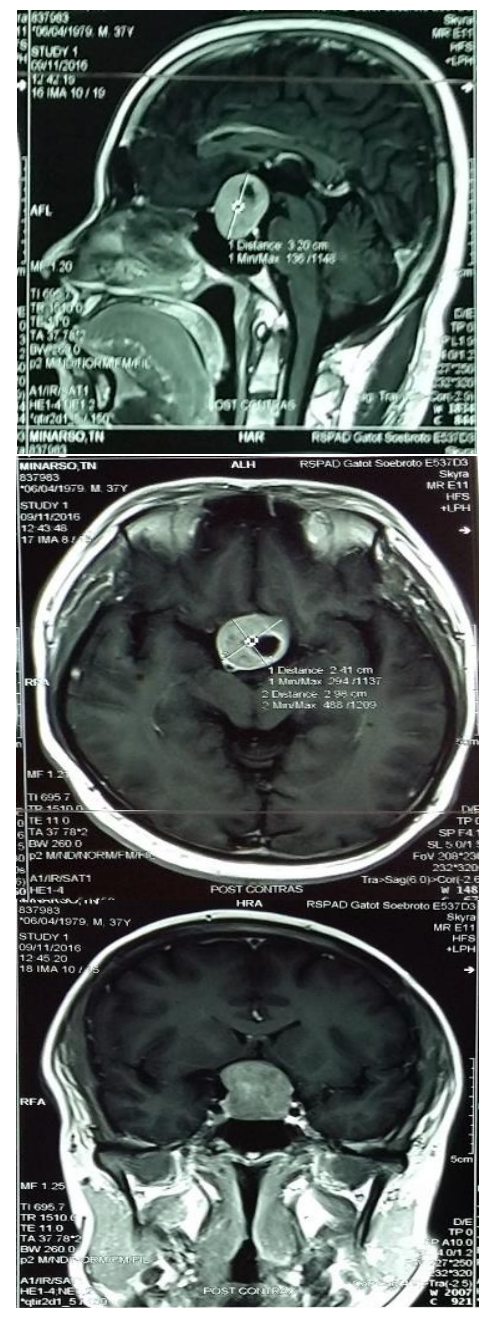

Figure 1. Preoperative MRI Scan.

After the surgery, the patient was recovered well. The pain management was sufficient. There was no epistaxis. The patient was discharged one week after operation without complication and follow up two weeks later in the outpatient clinic. There was no significant complain during follow up. We performed MRI scan six months after surgery and the result showed no tumor remission and complete decompression of brainstem structures.
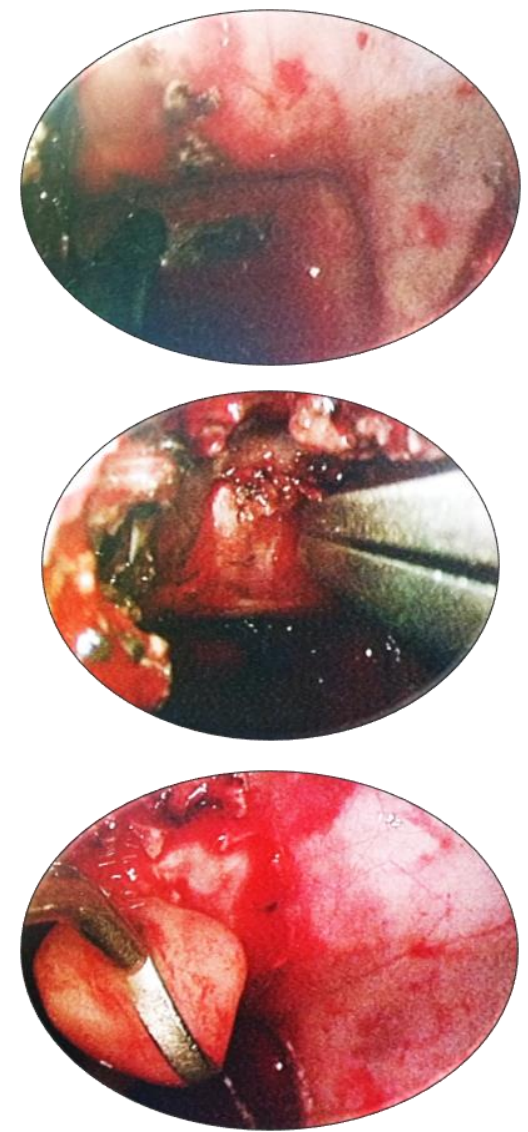

Figure 2. Intraoperative of Endoscopic Endonasal Transsphenoidal Surgery.

\section{DISCUSSION}

Based on this case, less than $5 \%$ of pituitary macroadenoma spread into the posterior cranial fossa. The treatment for these adenomas is complex. The other therapy with dopamine agonists is indicated for prolactinomas spreading into the next cranial fossa. ${ }^{4}$ Koutourousiou et al. said that surgical treatment of pituitary macroadenomas was a challenge for neurosurgeons. Because it is difficult to resect part of the tumor. Probably radiation therapy is considered as conservative management to prevent in long-term remission. ${ }^{5}$

In recent years, EETS has a wide application for pituitary adenomas case, because EETS is safe and has a good outcome post-surgery compared to the 
traditional surgery. The EETS provide a panoramic vision inside the surgical area, very close up from the anatomy, and easy to view the tumor. But there are still greater risk complications after surgery such as, postoperative cerebrospinal fluid (CSF) leakage and was reported from $0.9 \%$ to $6 \%$. CSF leakage can occur when the arachnoid around the tumor in the structure to the diaphragm sella region was torn, and the CSF comes out, then it will decrease the intracranial pressure. Moreover, epistaxis and sinusitis are the most complications event post-surgery. ${ }^{6}$ Strychowsky et al. made a systematic review from one prospective and nine retrospective articles. The conclusion suggested that endoscopic approach may result in better outcome, because less mean blood loss, shorter hospital stays and the duration of the surgery, and fewer nasal complications such as epistaxis. ${ }^{7}$

The advantages of EETS is that it does not utilize a nasal speculum, gives a clearer panoramic view, allow complete removal. The mortality rate related to pituitary tumors is very low. Morbidity related to pituitary macroadenomas is associated with a suprasellar expansion of the tumor to the optic chiasm and the cranial nerves, it may be caused permanent visual loss and ophthalmoplegia. For this case, the cure rate is $>50 \%$ on complete excision after the surgery. ${ }^{8}$ Mostly tumor larger than $1 \mathrm{~cm}$ has higher remission and may require adjuvant therapy such as radiotherapy or radiosurgery.

\section{CONCLUSION}

Endoscopic endonasal transsphenoidal surgery is a minimally invasive technique for tumor pituitary cases and better outcome post-surgery when compared to the traditional medicine. It provides a good surgical area view for the anatomy and less nasal cavity injuries. These surgeries method need to be performed by surgeons who have vast experience in endoscopic endonasal transsphenoidal surgery of skull base tumors.

\section{DISCLOSURE}

The authors declare that they have no conflict of interests.

\section{REFERENCES}

1. Torales J, Halperin I, Hanzu F, et al. Endoscopic endonasal surgery for pituitary tumors. Result in a series of 121 patients operated at the same center and by the same neurosurgeon. Endocrinol Nutr. 2014;61:410-6.

2. De Paiva Neto MA, Vandergrift A, Fatemi N, et al. Endonasal transsphenoidal surgery and multimodality treatment for giant pituitary adenomas. Clin Endocrinol. 2010;72:512-9.

3. Goel A, Nadkarni T, Muzumdar D. Giant pituitary tumors: a study based on surgical treatment of 118 cases. Surg Neuro. 2004;61:436-46.

4. Tropinskaya O, Shishkin L, Shkarubo A. A rare case of giant pituitary adenoma spreading in the posterior cranial fosaa. Voprosy neirokhirurgii im. 2009;4:54-6.

5. Koutourousiou M, Gardner PA, Fernandez-Miranda JC. Endoscopic endonasal surgery for giant pituitary adenomas: advantages and limitations. J Neurosurg. 2013;118:621-31.

6. Zhong $\mathrm{A}, \mathrm{Pu} \mathrm{J}$, Ruan $\mathrm{L}$, et al. The complications of endoscopic transsphenoidal surgery for pituitary neoplasms. Int $J$ Clin Exp Med. 2016;9:20026-31. 
7. Strychowsky J, Nayan S, Reddy K. Purely endoscopic transsphenoidal surgery versus traditional microsurgery for resection of pituitary adenomas: systematic review. J Otolaryngol Head Neck Surg. 2011;40:175-85.

8. Gsponer J, De Tribolet N, Deruaz JP, et al. Diagnosis, treatment, and outcome of pituitary tumors and other abnormal intrasellar masses.

Retrospective analysis of 353 patients. Medicine (Baltimore). 1999;78:236-69. 